\title{
Effect of Degree and Duration of Shade on Quality of Greenhouse Tomato
}

\author{
Martin P.N. Gent \\ Department of Forestry and Horticulture, Connecticut Agricultural \\ Experiment Station, P.O. Box 1106, New Haven, CT 06504-1106
}

Additional index words. blossom end rot, cracked skin, irregular shape, uneven ripening, yield

\begin{abstract}
Some amount of shade may be optimal to produce high-quality tomatoes in a greenhouse during summer months in the northeast United States. Simultaneous comparisons were made among greenhouse sections that were either not shaded or covered with reflective aluminized shadecloth that attenuated $15 \%, 30 \%$, or $50 \%$ of direct sunlight. The shadecloth was applied at the start of warm weather in June. The houses were shaded for the rest of the summer, and fruit was picked until late August. Total yield decreased linearly with increasing shade, but there was no significant difference among shade treatments in marketable yield. The fraction of fruit that was marketable was greatest for plants grown under $50 \%$ shade. This fraction was $9 \%$ greater than in a greenhouse with no shade in 2003 and $7 \%$ greater in 2004 and 2005. Cracked skin was the defect most affected by shade. Among sensitive cultivars, up to $35 \%$ of the fruit produced in greenhouses with no shade had cracked skin, whereas in greenhouses covered with $50 \%$ shade, only $24 \%$ to $26 \%$ of the tomatoes had cracked skin. There was no consistent trend for shade density in the fraction of fruit with green shoulder, blossom end rot, or irregular shape. The effect of shade increased with duration of shading. There was no effect of $50 \%$ shade compared with no shade on total yield within 20 days, but yield decreased by $20 \%$ in the interval from 25 to 45 days after shading and by $30 \%$ after 50 or more days of shading in 2005. Marketable yield only decreased after more than 45 days of shading for cultivars that were not sensitive to cracked skin or uneven ripening. Shade decreased fruit size over the entire season only in 2003. In general, shading increased the fraction of marketable tomato fruit without affecting fruit size.
\end{abstract}

Shade can increase total and market yield of tomato (Lycopersicon esculentum Mill.) grown in hot climates. Tomato plants grown in Egypt for the entire season under shade that attenuated $30 \%$ to $40 \%$ of sunlight had higher yields and more fruit than those grown without shade (Abdel-Mawgoud et al., 1996; El-Aidy, 1986). Increasing shade density above $40 \%$ decreased flowering and yield. For crops grown in Oklahoma, 63\% shade decreased yield in 1 year but not in another (Russo, 1993).

In climates with more moderate temperatures, shade typically reduces yield of tomato grown in a greenhouse. The structure and covering of a greenhouse reduces light intensity, so additional shade could be deleterious. In Brazil, a humid subtropical climate, $52 \%$ shade reduced yield by $20 \%$ (Sandra et al., 2003). In England, a cool and low-light environment, $23 \%$ shade reduced the yield by $20 \%$ (Cockshull et al., 1992). Movable shade, applied only during sunny periods, is less deleterious than constant shade. In England, a 1-week period of shade had no effect on yield (Adams et al., 2001). In Spain, mobile shade used only under intense sunlight increased marketable yield by $10 \%$ (Lorenzo et al., 2003). The benefit of shade

Received for publication 7 Nov. 2006. Accepted for publication 10 Jan. 2007.

I thank Michael Short, James McDonald, and Claudia Ritter for technical assistance.

E-mail Martin.Gent@po.state.ct.us. on quality in the latter study was attributable to less blossom end rot and cracked skin.

High light intensity can lead to several disorders in development and appearance of tomato fruit that affect quality (Dorais et al., 2001). Sunscald injury and uneven ripening are two disorders brought on by direct effects of light on fruit. Sunscald injury of tomato fruit increased with irradiance and air temperature and their combined effects (Adegoroye and Jolliffe, 1987). High temperature in conjunction with high irradiance also contributed to blotchy or uneven ripening (Lipton, 1970).

Cracks in the skin are one of the most common defects of tomatoes produced in the eastern United States (Peet and Willits, 1995). Sunlight plays a role in this defect. Field-grown fruit exposed to sunlight were more than twice as likely to develop cracks as shaded fruit (Whaley-Emmons and Scott, 1997). Plant water status also plays a role. Plants that were watered excessively had $20 \%$ more fruit with cracked skin than those with just sufficient water (Peet and Willits, 1995). Excess water also increased fruit weight. Conversely, when sodium chloride was used to increase electrical conductivity (EC) of the nutrient solution for tomato grown in rock wool, fewer fruit had cracked skin (Chretien et al., 2000). This treatment also resulted in a smaller fruit size. An increase in concentration of nutrients had a similar effect on cracking of cherry tomato fruit grown in hydroponics (Ohta et al., 1993). Thus, increasing solution EC or reduc- ing water supply prevents cracked skin but results in smaller fruit. These practices may not be welcomed by growers in the northeast United States, because they believe their customers want large fruit. One benefit of shade to increase the quality of tomato fruit is that shade may increase quality without reducing fruit size.

The climate in the northeast United States varies from cool and cloudy in winter and spring, with nights colder than $0{ }^{\circ} \mathrm{C}$, to warm and humid in summer with days warmer than $30{ }^{\circ} \mathrm{C}$. During a multiyear cultivar trial of greenhouse tomato, the average fraction of marketable fruit was $56 \%$ to $58 \%$ in years in which the houses were covered with $30 \%$ shadecloth, but only $32 \%$ to $44 \%$ in years in which no shade was applied (Gent, 2003, 2004). It is not clear whether shade applied in summer, or what density of shade, would improve quality of greenhouse tomato grown under these conditions. In the present report, yield and quality of tomato produced in summer in a nonshaded section of greenhouses was compared with that in sections covered with various densities of shadecloth.

\section{Materials and Methods}

Growth conditions. The experiments were conducted at Hamden, Conn. [lat. $42^{\circ} \mathrm{N}$, long. $73^{\circ} \mathrm{W}, 50 \mathrm{~m}$ above mean sea level (ASL)] in four hoop houses, $17.1 \mathrm{~m}$ long $\times 4.3 \mathrm{~m}$ wide $\times$ $2.7 \mathrm{~m}$ high, with a double glazing of $0.1-\mathrm{mm}$ clear polyethylene film. The air was heated by a forced-air heater and horizontal air flow equalized temperature throughout each house. Plants were grown in four rows of rock-wool slabs (Talent; Agrodynamics, East Brunswick, N.J.) fertilized with a complete nutrient solution of $5 \mathrm{~N}-7.9 \mathrm{P}-31.5 \mathrm{~K}$ (Tomato formula; Hydrogardens, Colorado Springs, Colo.), $\mathrm{Ca}\left(\mathrm{NO}_{3}\right)_{2}$, and $\mathrm{MgSO}_{4}$. This was supplied at every watering. Nitrogen was supplied at 100 to $200 \mathrm{mg} \cdot \mathrm{L}^{-1}$ during vegetative growth and fruit set. This concentration was reduced to $\approx 120 \mathrm{mg} \cdot \mathrm{L}^{-1}$ during fruit production. Potassium was supplied at 140 $\mathrm{mg} \cdot \mathrm{L}^{-1}$ initially, and it was increased to $\approx 190 \mathrm{mg} \cdot \mathrm{L}^{-1}$ during fruit production. The EC of the nutrient solution supplied to the plants during fruit production was 2.4, 2.1, and $2.0 \mathrm{dS} \mathrm{m}^{-1}$ in 2003, 2004, and 2005, respectively. The average EC of solution remaining in the slabs was $3.3,2.6$, and 4.0 $\mathrm{dS} \mathrm{m}^{-1}$, respectively, in these 3 years. The frequency of watering was adjusted according to plant size and sunlight integral, so nutrients were not depleted and adequate water remained in the root zone.

Seeds were germinated in January and seedlings were transplanted to a final spacing of 1.8 plants $/ \mathrm{m}^{2}$ in March. Greenhouses were heated to a minimum temperature of $14^{\circ} \mathrm{C}$ to $18^{\circ} \mathrm{C}$ until June. The ventilation temperature was $28{ }^{\circ} \mathrm{C}$ in early spring, falling to $24^{\circ} \mathrm{C}$ in early summer. Plants were pruned to a single stem and supported by string. Flower trusses were pruned to four or five fruit.

Four cultivars of greenhouse tomato (Lycopersicon esculentum Mill.) were grown 
in each year. 'Buffalo', 'Match', 'Quest', and 'Rapsodie' were grown in 2003. 'Cabernet' and 'Jetstar' were selected in 2004 and 2005 because they tended to produce a greater fraction of nonmarketable fruit, whereas 'Buffalo' and 'Quest' were retained from prior years. Seeds of 'Buffalo', 'Match', 'Quest', and 'Rapsodie' were obtained from Hydrogardens. Seeds of 'Cabernet' and 'Jetstar' were obtained from Holmes Seed Co. (Canton, Ohio).

Treatments. In 2003 through 2005, sections of greenhouses were either uncovered or covered with reflective aluminized shadecloth that provided $15 \%, 30 \%$, or $50 \%$ shade. The $15 \%$ shade was derived from the $30 \%$ shade by cutting a staggered array of square $0.3 \times 0.3-\mathrm{m}$ holes in the $30 \%$ shadecloth. The east and west half of each greenhouse was covered with a different shade, either a combination of none and $50 \%$ shade or a combination of $15 \%$ and $30 \%$ shade. A $4-m-$ wide strip of shadecloth covered the top of the houses. It was attached to a 1.8-m-wide black woven polyethylene shadecloth rated at $50 \%$ shade that covered the north and south sides of all houses, including those with no shade on top. The shade on the side reduced the variability among rows within a greenhouse (Hamer et al., 2004). The clear polyethylene sides were rolled up to a height of $1.5 \mathrm{~m}$ to improve ventilation when the shadecloth was applied.

In 2003, shade was applied 1 week before any fruit ripened. In 2004 and 2005, the first fruit ripened $\approx 3$ weeks before shade was applied. Shadecloth was applied on 5 June 2003, 23 June 2004, and 14 June 2005 and remained over the greenhouses for the rest of the summer. Fruit began to ripen on 13 June 2003, 2 June 2004, and 23 May 2005, and fruits were harvested at 4- to 5-day intervals through August. Fruit from four plants per subplot were combined for counting and weighing. Total yield, weight per fruit, and nature of defects of the fruit were recorded. Defects included radial and circular cracks in the skin, rough skin, green shoulder or uneven ripening, blossom end rot, and catfacing or irregular shape.

Environment. Shaded thermocouples and temperature humidity transmitters (model 500; Campbell Scientific, Logan, Utah) measured air temperature at a height of $1.5 \mathrm{~m}$ in the center of each greenhouse. A fine wire thermocouple (Omega Engineering, Stamford, Conn.) was pressed against the underside of an upper fully expanded leaf to record leaf temperature. These thermocouples were moved every few weeks and repositioned on a new upper leaf. A total of eight thermocouples were used to track leaf temperature simultaneously in two replicates of each shade treatment. Quantum sensors (model 190; LI-COR, Lincoln, Neb.) measured photosynthetic active radiation $(P A R)$ within the greenhouse above the height of the crop. Four sensors measured sunlight under each shade treatment simultaneously. Halfway through each year's experiment, the sensors were moved to sample another replicate of each shade treatment. Readings from each sensor were taken every minute, averaged hourly, and recorded. Another sensor measured ambient sunlight in an unobstructed location.

Experimental design and analysis. The experimental design was a split-plot with shade (greenhouses) as main plots and cultivar as subplots. There were four greenhouses in which shade treatments were replicated. The location of each shade treatment was varied within and among houses between years. Different cultivars were planted in each of the four rows within each shade treatment, and their location was varied between years. Each row of eight plants of one cultivar was split into two subplots of four plants to record yield characteristics.

Analysis of variance of yield components was conducted separately for each year and only included harvests while the greenhouses were shaded. Shade was analyzed as a continuous variable with linear and quadratic effects. Effects of cultivar and interactions between cultivar and shade were included in a general linear model in SYSTAT (version 10; SPSS, Richmond, Calif.). The cultivars were also analyzed separately in each year to determine the nature of any cultivar-by-shade interaction. The effect of shade on the rate of production and yield components was also calculated within consecutive periods of 20 to $25 \mathrm{~d}$ after shade was applied. Each period corresponded to five to six harvests. Each period was analyzed separately for main effects of shade and cultivar.

\section{Results}

Environment. The effect of shade on leaf temperature could only be detected under high sunlight intensity. There was no measurable difference in the dark or under low irradiance. When ambient irradiance was greater than $1600 \mu \mathrm{mol} \cdot \mathrm{m}^{-2} \cdot \mathrm{s}^{-1} P A R$, leaves that were not shaded were 1.5 to $1.8{ }^{\circ} \mathrm{C}$

Table 1. Environment in greenhouses covered with a double layer of polyethylene film and aluminized shadecloth. $^{\mathrm{z}}$

\begin{tabular}{|c|c|c|c|c|}
\hline \multirow[b]{3}{*}{ Year } & \multicolumn{4}{|c|}{ Daily integrated $P A R$} \\
\hline & \multirow{2}{*}{$\frac{\text { As a fraction of outside }}{\text { No shade }}$} & \multicolumn{3}{|c|}{ As a fraction of nonshaded section } \\
\hline & & $15 \%$ shade & $30 \%$ shade & $50 \%$ shade \\
\hline 2003 & 0.632 & 0.846 & 0.729 & 0.502 \\
\hline 2004 & 0.763 & 0.850 & 0.690 & 0.560 \\
\hline 2005 & 0.679 & 0.837 & 0.709 & 0.546 \\
\hline
\end{tabular}

\begin{tabular}{|c|c|c|c|c|}
\hline & \multicolumn{4}{|c|}{ Leaf temperature under high $P A R,{ }^{\circ} \mathrm{C}$} \\
\hline & None & $15 \%$ shade & $30 \%$ shade & $50 \%$ shade \\
\hline 2003 & 28.9 & 28.3 & 27.6 & 27.1 \\
\hline 2004 & 28.7 & 27.9 & 27.3 & 26.9 \\
\hline \multirow[t]{4}{*}{2005} & 31.1 & 30.4 & 29.9 & 29.6 \\
\hline & \multicolumn{4}{|c|}{ Air temperature, ${ }^{\circ} \mathrm{C}$} \\
\hline & \multicolumn{2}{|c|}{ Ambient } & \multicolumn{2}{|c|}{ In greenhouse } \\
\hline & Night & $\overline{\text { Day }}$ & Night & Day \\
\hline 2003 & 21.0 & 28.2 & 21.7 & 30.3 \\
\hline 2004 & 21.2 & 26.6 & 21.9 & 29.1 \\
\hline 2005 & 19.8 & 28.4 & 20.5 & 31.0 \\
\hline
\end{tabular}

${ }^{2}$ Daily integrated $P A R$ in a nonshaded section was compared with that outside, and $P A R$ in shaded sections was compared with that in the nonshaded sections. Leaf temperature was measured under ambient irradiance greater than $1600 \mathrm{uE} \mathrm{m}^{-2} \mathrm{~s}^{-1} P A R$. All values are averages over the period of shading. $P A R=$ photosynthetically active radiation.

warmer than those under $50 \%$ shade (Table 1 ). There was a proportionally smaller effect under less shade. The 24-hr integrals of sunlight intensity $(P A R)$ measured under the a sensor placed outside Compared with the nonshaded sections, the reduction in $P A R$ under each shade treatment was very close to the nominal rating of the shadecloth. The $P A R$ in the nonshaded sections was $\approx 30 \%$ less than that outside the greenhouse. The plastic cover was renewed before the 2004 $76 \%$ in that year. Air temperature did not vary between treatments. The temperature in all houses was less than $1{ }^{\circ} \mathrm{C}$ warmer than ambient at night and $\approx 2.5{ }^{\circ} \mathrm{C}$ warmer than ambient in the day during the period when plants were shaded.

Yield. When total and marketable yield were analyzed over the entire period after shade was applied, an increase in shade reduced total yield significantly in had the lowest yield, except for 'Cabernet' and 'Jetstar' in 2004. Nonshaded sections had the highest yield, except in 2005, when ost cultivars had the highest yield under $15 \%$ shade. Total yield under $50 \%$ shade was $26 \%, 13 \%$, and $11 \%$ less than that under tively. Despite on total yield, there was no significant effect of shade on marketable yield in any year. The marketable yield resulting from $50 \%$ shade was only $10 \%, 0 \%$, and $3 \%$ less than that from plants under no shade in 2003, 2004 , and 2005, respectively. The fraction of fruit that was marketable was greatest under $50 \%$ shade and least under no shade. Compared with the number of fruit produced the fruit was unmarketable when produced under no shade in 2003, 2004, and 2005, respectively.

HortScience Vol. 42(3) June 2007 
Table 2. Yield, weight per fruit, and fraction of fruit with defects averaged over four tomato cultivars as affected by density of shadecloth applied over greenhouses in 3 years.

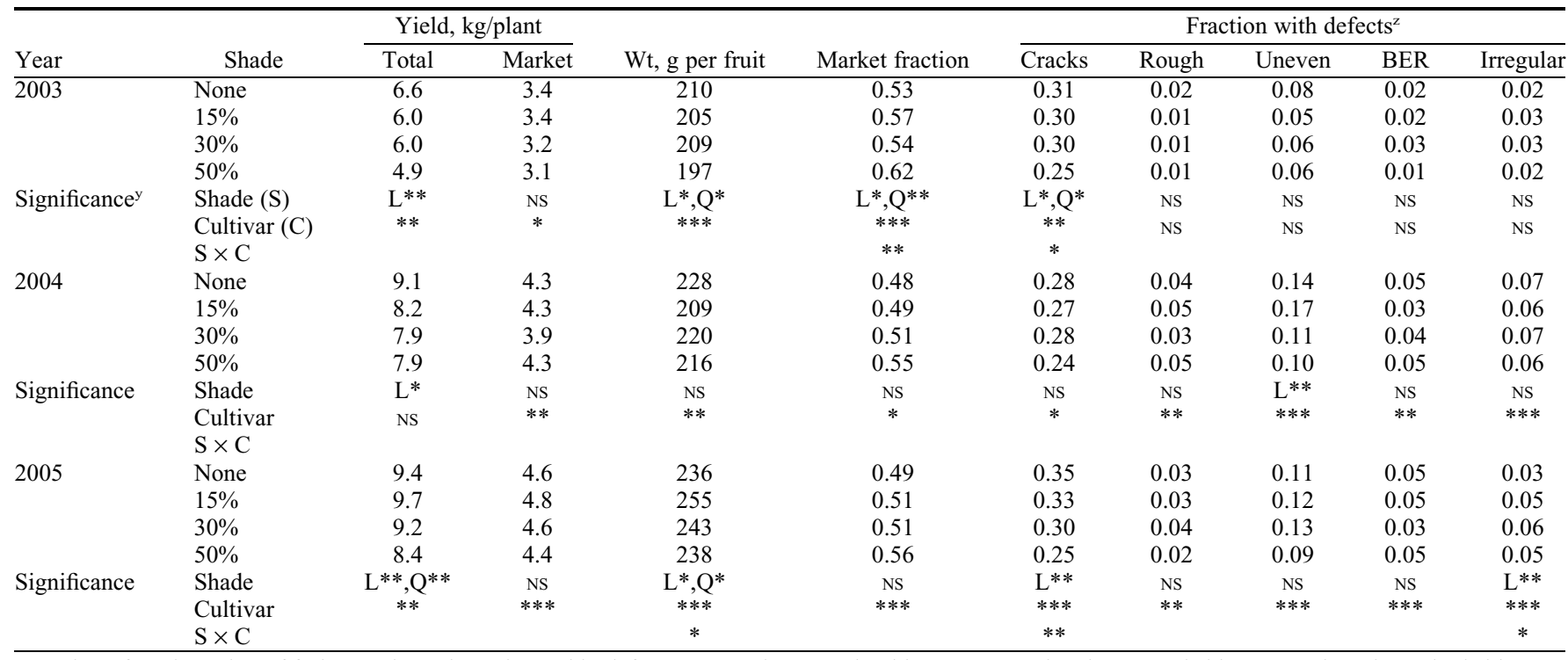

${ }^{\mathrm{z} F r a c t i o n}$ of total number of fruit. Cracks and rough are skin defects, uneven is green shoulder or uneven ripening, BER is blossom end rot, irregular is blossom end scar or open locule.

${ }^{\mathrm{y}}$ Significance of linear, L, or quadratic, Q, effects of shade.

$\mathrm{NS}^{*, * *, * * *}$ Nonsignificant or significant at $P<0.05,0.01$ or 0.001 , respectively.

Weight per fruit. The effects of shade on fruit weight were not consistent over the 3 years. In 2003, the weight per fruit picked from plants under $50 \%$ shade was less than that under the other shade treatments, and this pattern was similar to the effect of shade on total yield. In 2004, differences between shade treatments were not significant. In 2005 , the largest fruit were produced under $15 \%$ shade, and weight per fruit was similar under no shade and $50 \%$ shade.

Nature of defects. Radial cracks in the skin that propagated from the calyx was the defect that occurred with greatest frequency. Often, these were deep cracks that extended into the mesocarp. Plants in nonshaded sections produced more fruit with cracked skin than those under 50\% shade. In 2005, the decrease in the number of fruit with cracks was proportional to the shade density. Green shoulder or uneven ripening was the next most common defect. However, shade had an effect on this defect only in 2004 when plants that were not shaded had more uneven ripening that under other shade conditions. Defects such as rough skin, blossom end rot, or irregular shape occurred at a low frequency, typically less than $5 \%$. The effect of shade on the fraction of fruit with these defects varied among the 3 years of the experiment, in part because two of the cultivars grown in 2003 differed from those grown in 2004 and 2005.

Difference between cultivars. The cultivars differed in weight per fruit and the frequency of various defects such as fruit with cracked skin or irregular shape. There were some interactions among the effects of cultivar and shade. Such interactions occurred for the fraction of marketable fruit, the number of fruit with cracks in 2003 and 2005 , and for weight per fruit in 2005. Trends were similar in 2004 and 2005 , but the effects of shade were not as significant in 2004, primarily because there was more variation between subplots.

In 2003, the effect of shade on marketable fruit was different for 'Buffalo' than for the other cultivars. 'Buffalo' had the highest fraction of marketable fruit overall, but the marketable fraction was least under $50 \%$ shade (Table 3). For all cultivars except 'Buffalo', plants under $50 \%$ shade produced the fewest fruit with cracks. 'Buffalo' had the smallest fruit and fewest fruit with cracked skin, whereas 'Rapsodie' had the largest fruit and the most with cracked skin. The incidence of blossom end rot was lower in 2003 than in other years, because 'Jetstar' was not included.

In 2005, the weight per fruit of the various cultivars responded differently to shade. Shade had relatively little effect on 'Buffalo', whereas intermediate shade of $15 \%$ or $30 \%$ resulted in the largest fruit for the other cultivars (Table 4). The fraction of fruit with cracked skin varied in a similar manner. 'Buffalo' had a low fraction that did not vary with shade, whereas shade decreased the fraction of fruit with cracked skin for 'Cabernet and 'Jetstar'. The fraction of marketable fruit increased with shade for 'Cabernet' and 'Jetstar'.

In 2004 and 2005, 'Cabernet' had a high total yield, but it also had a low marketable yield and the greatest fraction of nonmarketable fruit. The poor market quality of 'Cabernet was primarily the result of cracks in the skin; up to $67 \%$ of the fruit had cracked skin. The incidence was $17 \%$ or less for 'Buffalo' and $25 \%$ or less for 'Quest' in 2005. 'Cabernet' produced the most fruit that ripened unevenly or had green shoulder, and 'Jetstar' had the most blossom end rot. 'Quest' had the most fruit with rough skin. There was no consistent trend across cultivars or over years in the effect of shade on rough skin, uneven ripening, or blossom end rot. 'Jetstar' had the most irregularly shaped fruit.

\section{Effect of Duration of Shade}

Rate of production. Analysis of yield over the entire period of shading obscured the fact that the effect of shade changed with time after it was applied. To visualize this aspect of the response, the yield was separated into 20 - to 25-d periods and each period was analyzed separately. The results are plotted as graphs for each of these periods with data for the 3 years superimposed on each graph. There were considerable differences between years. In 2003, fruit did not ripen until after shade was applied, so the rate of production was slow in the first period (Fig. 1). The rate of production in 2005 was greater than in 2004, particularly in the period from 25 to $45 \mathrm{~d}$ after shading. An accident with the watering system resulted in desiccation of the plants $\approx 20 \mathrm{~d}$ before shade was applied in 2004. Recovery from this incident was slow as shown by the relatively low yield during the period from 25 to $45 \mathrm{~d}$ postshade as compared with 2005. This desiccation increased variability between subplots compared with the other years. This is the primary reason why shade did not register as a significant affect in 2004. However, the figures show that many of the trends in 2004 were similar to those seen in 2005 .

Shade had no effect on production within the first $20 \mathrm{~d}$ after it was applied. There was a decrease in yield attributable to shade in the interval from 25 to $45 \mathrm{~d}$ after the shade was applied. This effect was significant in 2005 . The effect of shade on yield during this period 
Table 3. Yield, weight per fruit, and fraction of fruit with defects for four tomato cultivars as affected by density of shade in 2003.

\begin{tabular}{|c|c|c|c|c|c|c|c|c|c|c|}
\hline \multirow[b]{2}{*}{ Cultivar } & \multirow[b]{2}{*}{ Shade } & \multicolumn{2}{|c|}{ Yield, kg/plant } & \multirow[b]{2}{*}{$\mathrm{Wt}, \mathrm{g}$ per fruit } & \multirow[b]{2}{*}{ Market fraction } & \multicolumn{5}{|c|}{ Fraction with defects ${ }^{z}$} \\
\hline & & Total & Market & & & Cracks & Rough & Uneven & BER & Irregular \\
\hline & $15 \%$ & 5.9 & 4.1 & 184 & 0.70 & 0.21 & 0.00 & 0.01 & 0.02 & 0.04 \\
\hline Significance $^{\mathrm{y}}$ & & & & & $\mathrm{L}^{*}, \mathrm{Q}^{*}$ & & & $\mathrm{~L}^{*}, \mathrm{Q}^{*}$ & & \\
\hline Match & None & 7.4 & 3.1 & 215 & 0.41 & 0.36 & 0.01 & 0.15 & 0.03 & 0.03 \\
\hline Significance & & $\mathrm{L}^{*}, \mathrm{Q}^{*}$ & & $\mathrm{~L}^{*}$ & & & & & & \\
\hline Quest & None & 6.4 & 3.6 & 191 & 0.59 & 0.23 & 0.01 & 0.09 & 0.03 & 0.01 \\
\hline & $15 \%$ & 6.2 & 3.3 & 205 & 0.53 & 0.35 & 0.03 & 0.04 & 0.03 & 0.01 \\
\hline & $30 \%$ & 6.8 & 3.5 & 208 & 0.50 & 0.33 & 0.00 & 0.09 & 0.03 & 0.01 \\
\hline & $50 \%$ & 4.7 & 3.3 & 192 & 0.72 & 0.17 & 0.01 & 0.05 & 0.01 & 0.02 \\
\hline Significance & & $\mathrm{L}^{*}$ & & & & $\mathrm{~L}^{*}, \mathrm{Q}^{*}$ & & & & \\
\hline Significance & & $\mathrm{L}^{* *}, \mathrm{Q}^{*}$ & & & $\mathrm{~L}^{* *}, \mathrm{Q}^{*}$ & $\mathrm{~L}^{*}$ & $\mathrm{Q}^{*}$ & & & \\
\hline
\end{tabular}

${ }^{2}$ Fraction of total number of fruit. Cracks and rough are skin defects, uneven is green shoulder or uneven ripening, BER is blossom end rot, irregular is blossom end scar or open locule.

${ }^{\text {y }}$ Significance of linear, L, or quadratic, Q, effects of shade.

*** Significant at $P<0.05$ or 0.01 , respectively.

Table 4. Yield, weight per fruit, and fraction of fruit with defects for four tomato cultivars as affected by density of shade in 2005 .

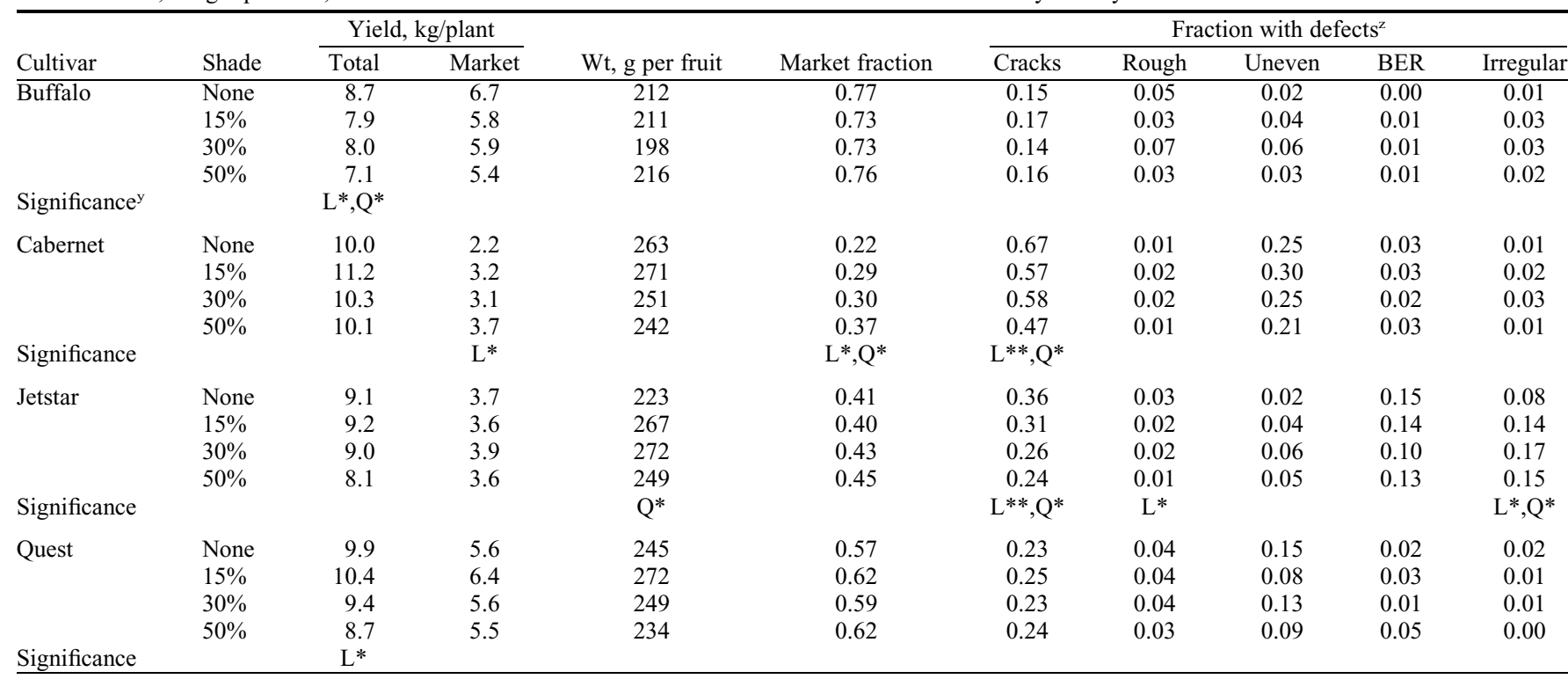

${ }^{\mathrm{z} F r a c t i o n}$ of total number of fruit. Cracks and rough are skin defects, uneven is green shoulder or uneven ripening, BER is blossom end rot, irregular is blossom end scar or open locule.

${ }^{y}$ Significance of linear, L, or quadratic, Q, effects of shade.

${ }^{*, * *}$ Significant at $P<0.05$ or 0.01 , respectively.

was slight, corresponding to a decrease in the rate of production of $\approx 20 \mathrm{~g}$ per day per plant under $50 \%$ shade compared with those in nonshaded sections. In contrast, when the plants had been under shade for $50 \mathrm{~d}$ or more, the effects of shade were more profound corresponding to a decrease in the rate of production of $30 \mathrm{~g}$ per day per plant under $50 \%$ shade compared with no shade. The production of all cultivars responded similarly to the duration and intensity of shade.

Weight per fruit. Within $20 \mathrm{~d}$ after shade was applied in 2003, there was great variability in weight per fruit picked from plants under the various shade treatments (Fig. 2). This was largely because the plants were not yet in full production and small differences in stage of development affected fruit size. There was a slight trend toward increasing fruit size with shade within $20 \mathrm{~d}$ after shade was applied in 2004 and 2005. However, these trends were not significant. After 25 or more days of shading, shade decreased weight per fruit consistently across years. This trend was significant after $45 \mathrm{~d}$ or more of shading in 2003 and 2005. It represented an $\approx 10 \%$ decrease in fruit size under $50 \%$ shade compared with no shade.

Fruit quality. The duration of shade affected the rate of production of marketable fruit less than the total rate of production. The shade treatments had no significant effect in any year up to $45 \mathrm{~d}$ after shading (Fig. 3 ). The only trend was a slight increase in marketable yield with shade in the first $20 \mathrm{~d}$ after it was applied in 2005 . Even after 50 or more days, the effect of shade on marketable yield was much smaller than that on total yield. The rate of production of marketable fruit under $50 \%$ shade was decreased by $\approx 5 \mathrm{~g}$ per day compared with no shade. There were distinct differences between cultivars up to $45 \mathrm{~d}$ after shading. 'Buffalo' and 'Quest' produced the most marketable fruit and 'Cabernet' produced the least. Thereafter, all cultivars had a 

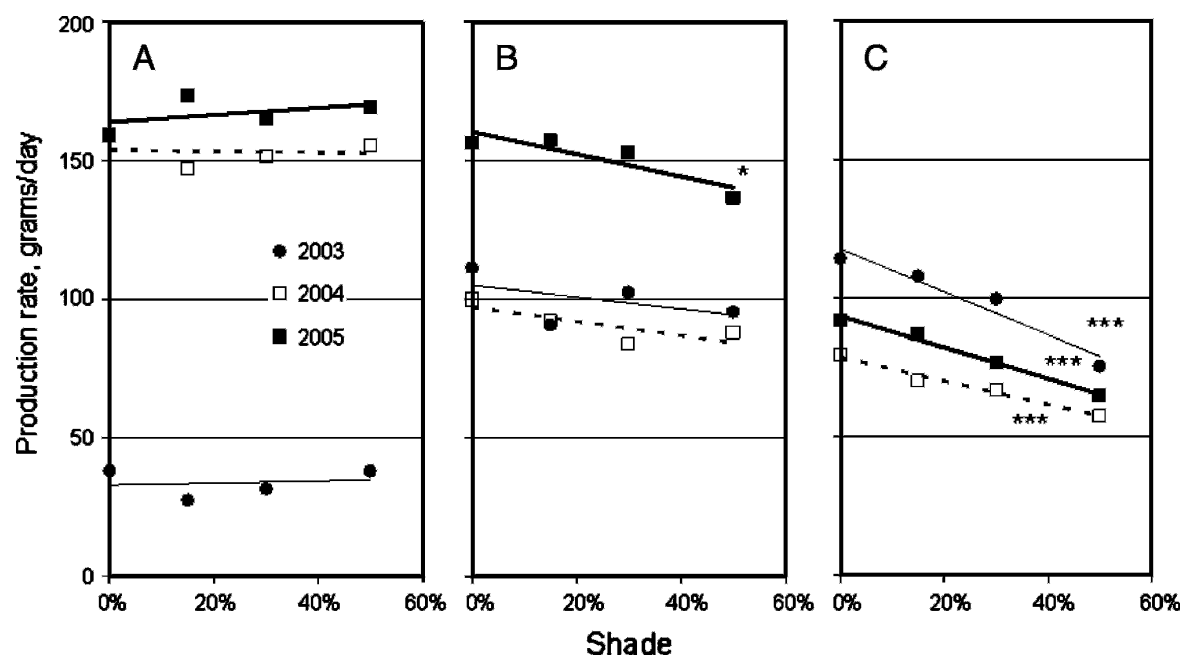

Fig. 1. Effect of duration and density of shade on total production rate of tomatoes per plant. Results for 3 years are separated into panels for intervals: (A) within $20 \mathrm{~d}$; (B) 25 to $45 \mathrm{~d}$; and (C) 50 or more days after shade was applied. ",*** Indicates linear effects of shade significant at $P<0.05$ or $P<0.001$, respectively.
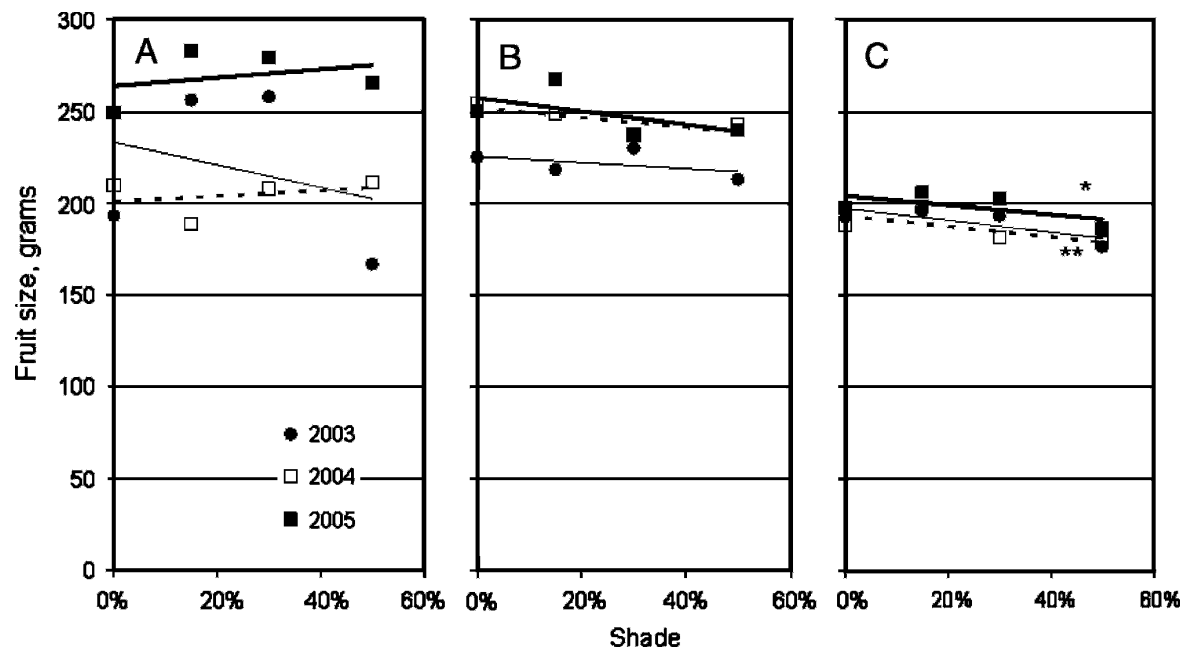

Fig. 2. Effect of duration and density of shade on weight per fruit of tomato. Results for 3 years are separated into panels for intervals: (A) within $20 \mathrm{~d}$; (B) 25 to $45 \mathrm{~d}$; and (C) 50 or more days after shade was applied. ${ }^{* * * *}$ Indicates linear effects of shade significant at $P<0.05$ or $P<0.01$, respectively.
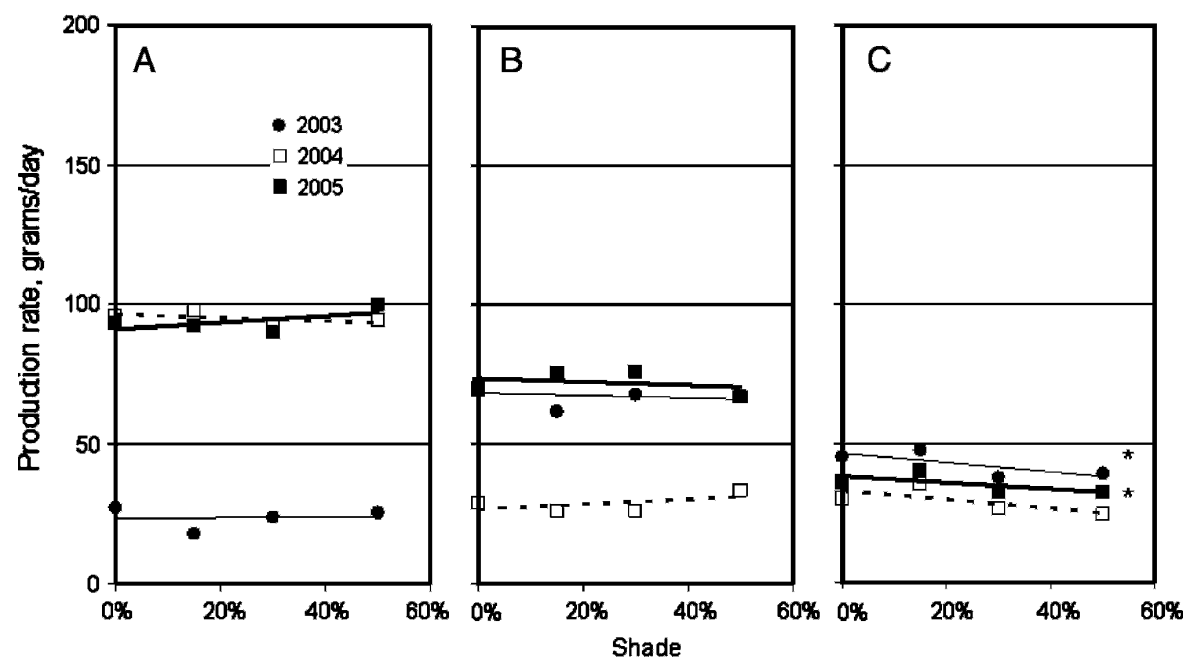

Fig. 3. Effect of duration and density of shade on marketable production rate of tomatoes per plant. Results for 3 years are separated into panels for intervals: (A) within $20 \mathrm{~d}$; (B) 25 to $45 \mathrm{~d}$; and (C) 50 or more days after shade was applied. "Indicates linear effects of shade significant at $P<0.05$. similar market yield. Marketable yield was similar in 2004 and 2005, except for the period from 25 to $45 \mathrm{~d}$ after shading.

When fruit quality was expressed in terms of the marketable fraction, there was relatively little effect in the first $20 \mathrm{~d}$ after application of shade. However, after more than $25 \mathrm{~d}$, there was a trend in which the fraction of marketable fruit increased with the amount of shade (Fig. 4). This increase with shade was significant in the period from 25 to 45 d in 2003 and 2004, and it was significant for the period after 50 or more days in 2003 and 2005. In this last period, $\approx 10 \%$ more of the fruit was marketable under $50 \%$ shade compared with no shade.

The marketable fraction varied among cultivars and years, particularly in the interval from 25 to $45 \mathrm{~d}$ after shade was applied. The fraction of marketable fruit was considerably lower in 2004 than 2005, particularly for 'Buffalo' and 'Quest'. In 2005, the trend toward a greater fraction of marketable fruit with shade after 50 or more days was mostly the result of an increase for the varieties 'Cabernet' and 'Jetstar'.

Nature of defects. In 2003, there were few fruit with cracked skin within $20 \mathrm{~d}$ after shade was applied, because the fruit were just beginning to ripen (Fig. 5), and these first fruit rarely developed cracks. More fruit had cracked skin soon after shade was applied in 2005 , and this fraction was decreased significantly by shade. Shade decreased the fraction of fruit with cracked skin 25 or more days after it was applied in each year. This effect was significant in the interval from 25 to $45 \mathrm{~d}$ after shade was applied in 2004 and 2005 , and after 50 or more days in 2003 and 2005. The effect of shade on cracks in the skin was consistent across cultivars in the period from 25 to $45 \mathrm{~d}$ after shade was applied. After 50 or more days, the effect differed among cultivars. Shade decreased the fraction of fruit with cracks for 'Cabernet' but increased this fraction for 'Quest' and 'Jetstar'.

There was a significant effect of shade on the incidence of green shoulder or uneven ripening only in the interval from 25 to $45 \mathrm{~d}$ after shading was applied in 2004 (data not shown). There was a linear decrease in uneven ripening with the amount of shade from a frequency of $25 \%$ under no shade to $\approx 17 \%$ under $50 \%$ shade. This may have been a delayed effect of desiccation, because there was much less uneven ripening in other periods in 2004 or in this period in 2005. There was no consistent affect of shade on blossom end rot or irregular shape as a function of time after shade was applied.

\section{Discussion}

Environment. Shade altered sunlight intensity with relatively little effect on air temperature in this study, because the radiation balance was similar for each greenhouse. Each house included two sections that were shaded to different extents, resulting in either 

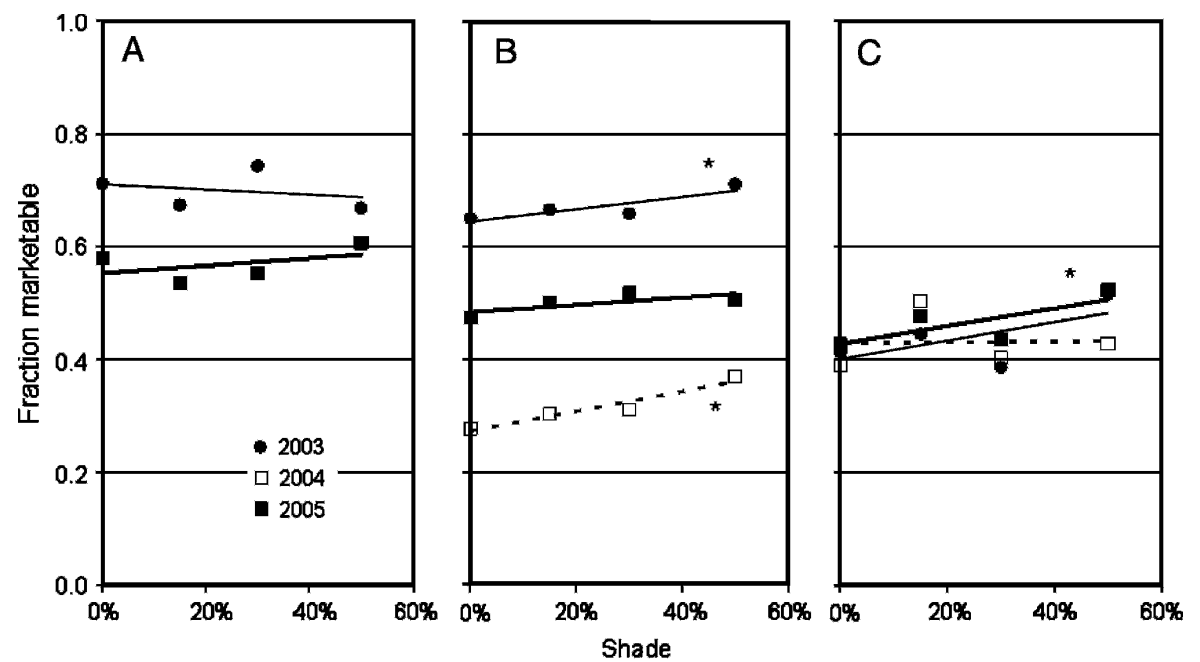

Fig. 4. Effect of duration and density of shade on marketable fraction of tomatoes. Results for 3 years are separated into panels for intervals: (A) within $20 \mathrm{~d}$; (B) 25 to $45 \mathrm{~d}$; and (C) 50 or more days after shade was applied. *Indicates linear effects of shade significant at $P<0.05$.
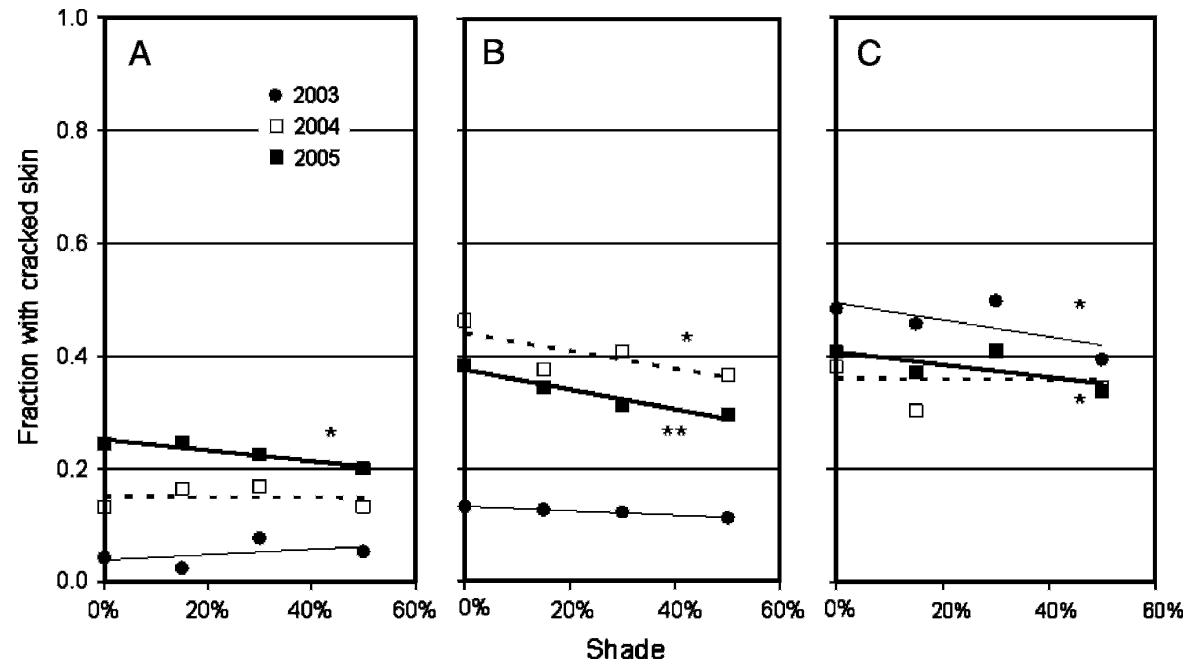

Fig. 5 Effect of duration and density of shade on fraction of tomatoes with cracks in the skin. Results for 3 years are separated into panels for intervals: (A) within $20 \mathrm{~d}$; (B) 25 to $45 \mathrm{~d}$; and (C) 50 or more days after shade was applied. ${ }^{*, * *}$ Indicates linear effects of shade significant at $P<0.05$ or $P<0.01$, respectively.

a $25 \%$ or $28 \%$ attenuation of sunlight averaged across both sections. In addition, the sides of the houses were rolled up so there was continuous ventilation. This design resulted in attenuation of sunlight in absence of any change in air temperature. The effect of shade on leaf temperature was small except under high irradiance. Consequently, any effects of treatment on yield and fruit quality were likely attributable to the response to irradiance rather than to temperature.

The design used here contrasts with many other studies of shade. In hot climates in which houses or crops were covered completely with black shadecloth rated at $30 \%$ to $50 \%$ transmittance, air temperature was reduced by 2 to $3{ }^{\circ} \mathrm{C}$ averaged over day and night (Abdel-Mawgoud et al., 1996; Russo, 1993; Smith et al., 1984). A study comparing white with black shadecloth showed that white shadecloth performed better in keeping the greenhouses cool (Willits, 2001). There were some slight differences between aluminized shading screens and whitewash on tomato photochemical efficiency; however, the change in photoinhibition was not directly proportional to shade rating (FernanadezRodriguez et al., 2001).

Fruit set. In hot climates, shade has a beneficial affect over no shade in that it increases flower number per plant, fruit set, and yield. Studies in Egypt suggested a 40\% shadecloth was optimum, with an increase to $50 \%$ or $60 \%$ shade generally decreasing plant growth and yield (El-Aidy, 1986; El-Gizawy et al., 1993). In this climate, changes in air temperature under shade were probably an important factor in plant response. Controlled-environment studies of the effect of heat stress on flowering and fruit set in tomato showed that consistent heat stress at $32 / 26{ }^{\circ} \mathrm{C}$ day/night temperature prevents fruit set, but this could be alleviated by a few days at a lower temperature or as little as three to $24 \mathrm{~h}$ of cool temperature immediately after anthesis (Sato et al., 2002). There was little effect of shade on fruit number in the present study, because the fruit were pruned to four or five fruit per truss. Nighttime temperatures were rarely as warm as $26^{\circ} \mathrm{C}$, and any effect of shade on flower bud temperature did not appear to be critical for fruit set.

Yield. The effect of shade on production was less than that expected from a proportionality to integrated $P A R$. If plants are put in darkness, the growth of tomato fruit in later stages of development is less affected by the carbohydrate starvation than the vegetative part of the plants or fruit early in development (Baldet et al., 2002; Gary et al., 2003). Thus, growth of established fruit appears to be little affected by carbohydrate availability. Tomato plants accumulate carbohydrate reserves in the stem and leaves that can be mobilized to support fruit growth (Hocking and Steer, 1994). The present study suggests these reserves can be used for an extended period of time after shade is applied. During this interval, the effect of shade on total yield could be attributed to changes in fruit size rather than fruit number as observed by others (Cockshull et al., 1992; Sandra et al., 2003).

Shading affected fruit production after 25 or more days of shade, and there was a larger relative decrease in yield after 50 or more days of shading. This may be the result of the effect of shade on fruit at an early stage of development. When $P A R$ was integrated over the entire period from anthesis to harvest for a single-truss tomato crop, there was a high correlation between total yield and light intensity (McAvoy et al., 1989). In the latter study, fruit growth rate was roughly proportional to integrated $P A R$, because the duration from anthesis to harvest varied much less than integrated $P A R$. Thus, effects on yield of tomato are much greater when shading or reduced carbohydrate availability occurs at or before fruit set compared with shade applied during rapid fruit growth.

Fruit quality. Radial cracks in the skin was the most frequent defect, and it was responsive to shading. Other studies of this defect have focused on water management as a method to prevent cracking. In soil or bag culture, an increase in watering in terms of frequency or volume resulted in more cracked fruit and larger fruit size (Abbott et al., 1985; Peet and Willits, 1995). Lowering plant water potential in hydroponics by increasing solution EC had the opposite effect of increasing fruit quality but decreasing fruit size (Chretien et al., 2000; Ohta et al., 1993). In the present study, the water supply was altered according to shading treatment, and EC showed little variation among shade treatments (data not shown). The EC of the nutrient solution was likely not the factor that caused cracking.

However, shade influences another aspect of plant water potential that could affect the 
development of cracks in the skin of fruit. Shade decreases transpiration and the response of leaf transpiration to ambient sunlight (Medrano et al., 2004). The midday decrease in plant water potential should be less for plants grown under shade than for those with no shade. This may be an important factor in controlling cracking under shade. The effect of shade on transpiration may be as important for fruit growth as its effect on photosynthesis and carbohydrate status. Pearce et al. (1993) noted that under high irradiance during the day, the rate of fruit swelling was reduced to half of that expected from the temperature response in the dark. This was presumed to be the result of plant water stress brought on by transpiration. Under Mediterranean conditions, a low vapor pressure deficit that reduced transpiration increased fruit weight of tomato but decreased dry matter content (Bertin et al., 2000).

Exposure of fruit to sunlight could change the water potential of the fruit directly and cause the skin to crack as a result of heating of the fruit surface. Field-grown fruit exposed to sunlight had more cracks than shaded fruit, 49 versus 20\% (Whaley-Emmons and Scott, 1997). Shading clearly would ameliorate this effect in proportion to the reduction in sunlight intensity. Secondarily, plant leaf area tends to increase under low-light conditions, and shading may result in better coverage of the fruit by leaves. This is an aspect that is hard to quantify and was not measured in the current study.

Various other defects of tomato fruit have been related to sunlight intensity or shading. More fruit with symptoms of uneven ripening were produced under nonshaded than under shaded conditions both under cool and lowlight conditions (Cockshull et al., 1992) and hot conditions with more intense sunlight (Abdel-Mawgoud et al., 1996; El-Gizawy et al., 1993). In the present study, 'Cabernet' was the only cultivar with a high frequency of uneven ripening. A trend toward less uneven ripening with increasing shade density was only significant in 2004. The frequency of blossom end rot (BER) has been correlated with integrated sunlight intensity (Ho et al., 1993). The improvement of tomato quality resulting from the use of moveable shade over a greenhouse in Spain was attributable to reduction in the incidence of BER (Lorenzo et al., 2003). Neutral or white shade also lowered the incidence of BER in a comparison of shade treatments in England (Tatabaie et al., 2004). In the present study, 'Jetstar' was the only cultivar that exhibited much BER, and there was no response to shade.

'Jetstar' was also the cultivar most prone to produce fruit with open locules or irregular shape. This was the only defect that occurred more often under shade in 2005. This defect has been primarily related to cool night temperatures (Dorais et al., 2001), However, shade treatments did not differ in night temperature in the present study.

When shadecloth was applied over a greenhouse at or after fruit began to ripen, it reduced the number of fruit with cracked skin while having relatively little effect on weight per fruit. Although shade did not increase marketable yield, the marketable fraction was least without shade and greatest under $50 \%$ shade. If shade were applied only during periods of intense sunlight, using a moveable shade system, it would have a less adverse effect on yield, but shading should still have a positive effect on the marketable fraction. An economic benefit to shade is that less labor would be used to pick nonmarketable fruit. The labor cost per unit of marketable fruit would be lower under some degree of shade than without shade.

\section{Literature Cited}

Abbott, J.D., M.M. Peet, D.H. Willits, and R.E. Gough. 1985. Water management of greenhouse tomatoes. HortScience 20:688-690.

Abdel-Mawgoud, A.M.R., S.O. El-Abd, S.M. Singer, A.F. Abou-Hadid, and T.C. Hsiao. 1996. Effect of shade on the growth and yield of tomato plants. Acta Hort. 434:313320.

Adams, S.R., V.M. Valdes, C.R.J. Cave, and J.S. Fenlon. 2001. Impact of changing light levels and fruit load on the pattern of tomato yields. J. Hort. Sci. 76:368-374.

Adegoroye, A.S. and P.A. Jolliffe. 1987. Some inhibitory effects of radiation stress on tomato fruit ripening. J. Sci. Food Agr. 39:297-302.

Baldet, P., C. Devaux, C. Chevalier, R. Brouquisse, and P. Raymond. 2002. Contrasted responses to carbohydrate limitation in tomato fruit at two stages of development. Plant Cell Environ. 25:1639-1649.

Bertin, N., S. Guichard, C. Leonardi, J. Longuenesse, D. Langlois, and B. Navez. 2000. Seasonal evolution of the quality of fresh glasshouse tomatoes under Mediterranean conditions as affected by air vapor pressure deficit and plant fruit load. Ann. Bot. (Lond.) 85:741-750

Chretien, S., A. Gosselin, and M. Dorais. 2000. High electrical conductivity and radiation based water management improve fruit quality of greenhouse tomatoes grown in rockwool. HortScience 35:627-631.

Cockshull, K.E., C.J. Graves, and C.R.J. Cave. 1992. The influence of shading on yield of glasshouse tomatoes. J. Hort. Sci. 67:11-24.

Dorais, M., A.P. Papadopoulos, and A. Gosselin. 2001. Greenhouse tomato fruit quality. Hort. Rev. (Amer. Soc. Hort. Sci.) 26:239-319.

El-Aidy, F. 1986. Tomato production under simple protective tunnels in Egypt. Acta Hort. 190:511-514.

El-Gizawy, A.M., M.M.F. Abdallah, H.M. Gomaa, and S.S. Mohamed. 1993. Effect of different shading levels on tomato plants: Yield and fruit quality. Acta Hort. 323:349-354.

Fernanadez-Rodriguez, E.F., D. Perez, F.C. Ferre, J.F. Vadillos, and A. Kenig. 2001. Effect of aluminized shading screens vs whitewash on tomato photochemical efficiency under a non heated greenhouse. Acta Hort. 559:279-284.

Gary, C., P. Baldet, N. Bertin, C. Devaux, M. Tchamitchian, and P. Raymond. 2003. Time course of tomato whole plant respiration and fruit and stem growth during prolonged darkness in relation to carbohydrate reserves. Ann. Bot. (Lond.) 91:429-438.

Gent, M.P.N. 2003. Greenhouse tomato cultivar trials in Connecticut 1999-2002. Connecticut Agr. Expt. Station Bull. 990.
Gent, M.P.N. 2004. Yield of greenhouse tomato in response to supplemental nitrogen and potassium. Acta Hort. 633:341-348.

Hamer, P.J.C., S.R. Adams, and V.M. Valdes. 2004. Design and evaluation of a shade screen to overcome within row variability of tomato crops grown in small experimental class house compartments. Acta Hort. 633:67-73.

Ho, L.C., R. Belda, M. Brown, J. Andrews, and P. Adams. 1993. Uptake and transport of calcium and the possible causes of blossom end rot in tomato. J. Expt. Bot. 44:509-518.

Hocking, P.J. and B.T. Steer. 1994. The distribution of assimilate in tomato with special reference to stem reserves. Ann. Bot. (Lond.) 73:315-325.

Lipton, W.J. 1970. Effects of high humidity and solar radiation on temperature and color of tomato fruits. J. Amer. Soc. Hort. Sci. 95:680-684.

Lorenzo, P., M.C.S. Guerro, E. Medrano, M.L. Garcia, I. Caparros, and M. Giminez. 2003. External greenhouse mobile shading effect on microclimate water use efficiency and the yield of a tomato crop grown under different salinity levels of the nutrient solution. Acta Hort. 609:181-186

McAvoy, R.J., H.W. Janes, B.L. Godfriaux, M. Secks, D. Duchai, and W.K. Wittman. 1989. Effect of total available photosynthetic flux on single truss tomato growth and production. J. Hort. Sci. 64:331-338.

Medrano, E., P. Lorenzo, M.C.S. Guerro, M.L. Garcia, I. Caparros, and M. Giminez. 2004. Influence of external greenhouse mobile shading on tomato crop transpiration. Acta Hort. 659:195-199.

Ohta, K., N. Ito, T. Hosoki, K. Endo, and O. Kajikawa. 1993. Influence of nutrient solution concentration on cracking of cherry tomato fruit grown hydroponically. J. Jpn. Soc. Hort. Sci. 62:407-412.

Pearce, B.D., R.I. Grange, and K. Hardwick. 1993. The growth of young tomato fruit II: Environmental influences on glasshouse crops grown in rockwool or nutrient film. J. Hort. Sci. 68:13-23.

Peet, M.M. and D.H. Willits. 1995. Role of excess water in tomato fruit cracking. HortScience 30:65-68.

Russo, V.M. 1993. Shading of tomato plants inconsistently affects fruit yield. HortScience 28:1133.

Sandra, M.A., J.L. Andriolo, M. Witter, and T.D. Ross. 2003. Effect of shading on tomato plants grown under greenhouse. Hort. Brasilias 21:642-645. (Abstract).

Sato, S., M.M. Peet, and J.F. Thomas. 2002. Determining critical pre and post anthesis periods and physiological processes in Lycopersicon esculentum Mill. exposed to moderately elevated temperatures. J. Expt. Bot. 53:1187-1195.

Smith, I.E., M.J. Savage, and P. Mills. 1984. Shading effects on greenhouse tomatoes and cucumbers. Acta Hort. 148:491-500.

Tatabaie, S.J., P. Hadley, and P.J. Gregory. 2004. Effect of a glasshouse IR filter on yield quality and calcium concentration in tomato fruit. Acta Hort. 633:167-172.

Whaley-Emmons, C.L. and J.W. Scott. 1997. Environmental and physiological effects on cuticle cracking in tomato. J. Amer. Soc. Hort. Sci. 122:797-801.

Willits, D.H. 2001. Effect of cloth characteristics on the cooling performance of external shade cloths for greenhouses. J. Agr. Eng. Res. 79:331-340. 